\title{
Clinical value of detection of immune index and inflammatory reaction changes in patients with autoimmune disease
}

\author{
X.J. Zhang ${ }^{1}$, H.Y. Zhou ${ }^{1}$ and Y. $\mathrm{Li}^{2}$ \\ ${ }^{1}$ Clinical Laboratory, Binzhou People's Hospital, Binzhou, China \\ ${ }^{2}$ Blood Transfusion Department, Binzhou People's Hospital, Binzhou, China \\ Corresponding author: X.J. Zhang \\ E-mail: xjzhangxjz@163.com
}

Genet. Mol. Res. 15 (3): gmr.15038745

Received April 28, 2016

Accepted June 22, 2016

Published September 23, 2016

DOI http://dx.doi.org/10.4238/gmr.15038745

Copyright (C) 2016 The Authors. This is an open-access article distributed under the terms of the Creative Commons Attribution ShareAlike (CC BY-SA) 4.0 License

\begin{abstract}
Previous studies have shown a close correlation between the generation of $\mathrm{B}$ cell autoantibodies and imbalances in $\mathrm{T}$ lymphocyte subpopulations and the occurrence of disease. In this study, we have analyzed the effects of abnormal expression of CD4+CD25+-regulatory $\mathrm{T}$ cells, $\mathrm{T}$ lymphocyte subpopulations, immunoglobulins, complement factors, inflammatory factors, and adhesion molecules in the peripheral blood on the occurrence and development of autoimmune disease. Eighty patients with autoimmune disease were randomly (equally) divided into active-stage and stable-stage disease groups (according to pre-defined criteria). Fifty healthy people were recruited to the control group. The above-mentioned indices were detected by flow cytometry, immunity transmission turbidity, and enzyme-linked immunosorbent assay. We observed an obvious decrease in the $\mathrm{CD} 4+\mathrm{CD} 25+-$ regulatory T cell, CD4+ cell, CD4+/CD8+ cell, NK cell, $\mathrm{C}_{3}$, and $\mathrm{C}_{4}$ expression in all three groups; however, this decrease was statistically significant in
\end{abstract}


the active-stage group $(\mathrm{P}<0.05)$. Alternately, we observed a significant increase in the expression of CD8+ cells, immunoglobulin (Ig) A, IgG, IgM, tumor necrosis factor- $\alpha$, interleukin (IL)-10, IL-17, interferon- $\gamma$, intercellular adhesion molecule-1, vascular cell adhesion molecule-1, and E-selectin expression in the active-stage group $(\mathrm{P}<0.05)$. Therefore, inflammatory reactions and immune dysfunction occurs during the active-stage of autoimmune disease, and detection of the immune indices and inflammatory and adhesion factors could help evaluate the immune stage in these patients, providing an experimental basis for the determination of disease progression and clinical treatment.

Key words: Autoimmune disease; $\mathrm{T}$ lymphocyte subpopulation; Inflammatory factor

\section{INTRODUCTION}

Autoimmune disease can be T cell-mediated (multiple sclerosis, MS) or immune complex-mediated (comprising autoantibodies and tissue surface antigens or soluble antigens) (Liu and Davidson, 2011; Fairfax et al., 2012). The development of autoantibody-induced diseases, such as systemic lupus erythematosus (SLE), myasthenia gravis, and sicca syndrome, can be attributed to tolerance deficiency of specific B cells that produce autoantibodies (Zouali and $\mathrm{Uy}, 2013)$. Helper T cells are known to promote the response of self-reactive B cells in diseases induced by autoantibodies, such as immunoglobulin G (IgG) (Vincent et al., 2014). Recent studies have indicated that self-reactive B cells play major roles in T cell-induced autoimmune diseases, such as MS and type 1 diabetes mellitus (Stohl et al., 2012; Szydłowski et al., 2014). Therefore, the consensus is that autoimmune dysfunction is coordinated and mediated by T and B cells (Lisak and Ragheb, 2012; Vincent et al., 2013).

Over 30 types of autoimmune diseases, a majority of which are primary autoimmune diseases involving multiple factors, such as genetic or environmental factors, or abnormal immune or sex hormone (and its receptor) regulation, have been reported so far (Chong et al., 2014). Recent studies have shown the increased usage of peripheral blood to clinically evaluate the active degree of disease and provide a reference for the determination of disease progress and selection of treatment method (Haugen et al., 2014). In this study, we have discussed the clinical significance of the detection of $\mathrm{CD} 4+\mathrm{CD} 25+$-regulatory $\mathrm{T}$ cells, $\mathrm{T}$ lymphocyte subpopulations, immunoglobulins, complement factors, inflammatory factors, and adhesion molecules in the peripheral blood of patients with autoimmune disease, to provide an experimental basis for the diagnosis and treatment of autoimmune disease.

\section{MATERIAL AND METHODS}

\section{General data}

Eighty patients with various autoimmune diseases (46 males and 34 females; age range: $12-67$ years; average age: $36.88 \pm 13.81$ years) who received treatment at the Binzhou People's Hospital, Shandong, China, between May 2013 and May 2014 were recruited to this study. Autoimmune disease was diagnosed based on conformance with the relevant diagnostic

Genetics and Molecular Research 15 (3): gmr.15038745 
criteria for autoimmune disease (Volpe et al., 2008). The study population comprised 25 patients with SLE, 25 patients with rheumatoid arthritis, and 30 patients with ankylosing spondylitis. Patients with acquired immune deficiency syndrome (AIDS), hyperthyrosis, or other immune system diseases, severe liver and renal disease, diabetes, malignant tumors, or infectious diseases, those who had taken immunosuppressors or non-steroidal antipyretic analgesics prior to recruitment, or females in their gestation period, suckling period, or menstrual period (at the start of the study) were excluded from this study. The subjects were evenly divided into activestage and stable-stage groups according to the Valentjin method, improved disease activity criteria of European League against Rheumatism (three variables) (DAS28-3), and Bath ankylosing spondylitis disease activity index (BASDAI). Fifty healthy people who underwent a physical examination at the Binzhou People's Hospital during the same time period were recruited to the control group (19 males and 31 females; age range: 18-65 years; average age: $40.35 \pm 13.77$ years). The study was approved by the Ethics Committee of the hospital, and signed informed consent was obtained from all patients prior to the experiment. The patients in the three groups did not differ significantly in terms of their age and gender ratio $(\mathrm{P}>0.05)$.

\section{Instruments and reagents}

The 960 microplate reader (Sigma-Aldrich, St. Louis, MO, USA), EPICS XL flow cytometer (Beckman Coulter, Brea, CA, USA), and the fully automated 7080 biochemical analyzer (Hitachi, Tokyo, Japan) were used in this study. A standard enzyme-linked immunosorbent assay (ELISA) kit was obtained from Boster Biological Company (Valley Ave, CA, USA).

\section{Observation index and detection method}

Fasting peripheral venous blood $(3 \mathrm{~mL})$ was obtained from each subject; the blood samples were centrifuged at $12,000 \mathrm{~g}$ for $10 \mathrm{~min}$ and the supernatant was stored at $-80^{\circ} \mathrm{C}$.

\section{Detection of T lymphocyte subpopulations}

The CD4+CD25+-regulatory $\mathrm{T}$ cell and $\mathrm{T}$ lymphocyte $(\mathrm{CD} 3+, \mathrm{CD} 4+$, and $\mathrm{CD} 8+)$ subpopulation and natural killer (NK) cell levels were detected by flow cytometry as follows: fluorescence-labeled monoclonal antibodies against CD4/CD8/CD3 $(10 \mu \mathrm{L}), \mathrm{CD} 3 / \mathrm{CD} 16+56+$ $(10 \mu \mathrm{L}), \mathrm{CD} 4 \mathrm{CD} 25$ (Foxp3; $10 \mu \mathrm{L}$ ) were added to a $12-\mathrm{mm} \times 75-\mathrm{mm}$ flow cytometry tube. One hundred microliters of peripheral blood was subsequently added, and the tubes were cultured at room temperature in the dark for $15 \mathrm{~min}$. Isotype controls were set up. Optilysec hemolysin $(500 \mu \mathrm{L})$ was added to the tubes and mixed by vortexing. The tubes were then incubated at room temperature for $10 \mathrm{~min}$ in the dark. The cells were centrifuged again at 6000 $g$ for $5 \mathrm{~min}$ and the supernatant was removed. The cells were centrifuged again with $1 \mathrm{~mL}$ PBS for $5 \mathrm{~min}$ and the supernatant removed. The cells were washed and resuspended in $1 \mathrm{~mL}$ PBS. The single-cell suspension was detected.

\section{Detection of Ig and complement levels}

IgA, IgG, IgM, $\mathrm{C}_{3}$, and $\mathrm{C}_{4}$ levels were detected using a fully automated biochemical analyzer and immunity transmission turbidity.

Genetics and Molecular Research 15 (3): gmr.15038745 


\section{Detection of serum inflammatory factors and adhesion molecules}

The tumor necrosis factor (TNF)- $\alpha$, interleukin (IL)-10, IL-17, interferon (IFN)- $\gamma$, intercellular adhesion molecule (ICAM-1), vascular cell adhesion molecule (VCAM)-1, and E-selectin levels were detected by ELISA as described below: the standard kits and samples were cooled at $27^{\circ} \mathrm{C}$ for $30 \mathrm{~min}$. The standard substance, blank control, and sample wells were set up by adding $50 \mu \mathrm{L}$ standard substance, sample, and blank control separately into the wells. The position of each well was recorded. The wells were set up in triplicate. Assay diluent (100 $\mu \mathrm{L}$ ) was added to each well. The plate was sealed with a microplate sealer and cultured on a micro-horizontal oscillator $(500 \pm 50 \mathrm{rpm})$ at room temperature for $3 \mathrm{~h}$. Subsequently, the liquid from each well was discarded, and each well was washed thrice with $400 \mu \mathrm{L}$ washing liquid; the procedure was repeated four times. The wells were washed; the liquid was removed, and the ELISA plate was reversed and dried with clean bibulous paper. Subsequently, the cells were incubated with $200 \mu \mathrm{L}$ B cell activation factor belonging to the TNF family (BAFF/BLy $\mathrm{S})$ or dsDNA conjugate. The plate was covered with a new microplate sealer and cultured on a micro-horizontal oscillator at room temperature for $1 \mathrm{~h}$. The ELISA plate was washed as described above. Subsequently, $200 \mu \mathrm{L}$ substrate solution was added to each well, and the cells were incubated at room temperature in the dark for $30 \mathrm{~min}$. Fifty microliters stopping solution was added to each well. The color of the liquid in the well developed from blue to yellow; however, if the liquid turned green or no obvious color changes were observed, the ELISA plate was mildly beaten to ensure full mixing. The absorbance (optical density) of each well was measured at $450 \mathrm{~nm}$ within 15 min after the termination of the reaction. The standard curve regression equation was calculated using the concentration of standard substances and the corresponding OD value. The concentration of the sample was calculated using the regression equation, based on the OD value of the sample. The final concentration was thrice that of the measured concentration.

\section{Statistical analysis}

SPSS v.20.0 was used for data analysis. The data are reported as the means \pm standard deviation (SD) and analyzed by single-factor analysis of variance (ANOVA). Comparison between groups was performed using the q-test. The difference was considered to be statistically significant when $\mathrm{P}<0.05$.

\section{RESULTS}

\section{Peripheral blood cell subpopulations}

We observed a significant decrease in the CD4+CD25+-regulatory T cell, CD4+/ $\mathrm{CD} 8+$ cell, and NK cell population $(4.3 \pm 0.7$ vs $7.4 \pm 1.4$ vs $8.8 \pm 1.4 ; 24 \pm 3$ vs $41 \pm 7$ vs $49 \pm 9 ; 0.71 \pm 0.09$ vs $1.78 \pm 0.28 v s 1.79 \pm 0.30 ; 6.9 \pm 1.1 v s 13.9 \pm 1.8 v s 16.1 \pm 2.3)$ and a significant increase in the CD8+ cell expression (48 $\pm 8 v 28 \pm 5$ vs $26 \pm 3)$ in the activestage group, compared to the stable-stage and control groups $(\mathrm{P}<0.05)$. However, the CD3+ subpopulation did not differ significantly $(\mathrm{P}>0.05)$. Moreover, the differences in the abovementioned indices between the control and stable-stage groups were not significant $(\mathrm{P}>0.05$; Figure 1). 


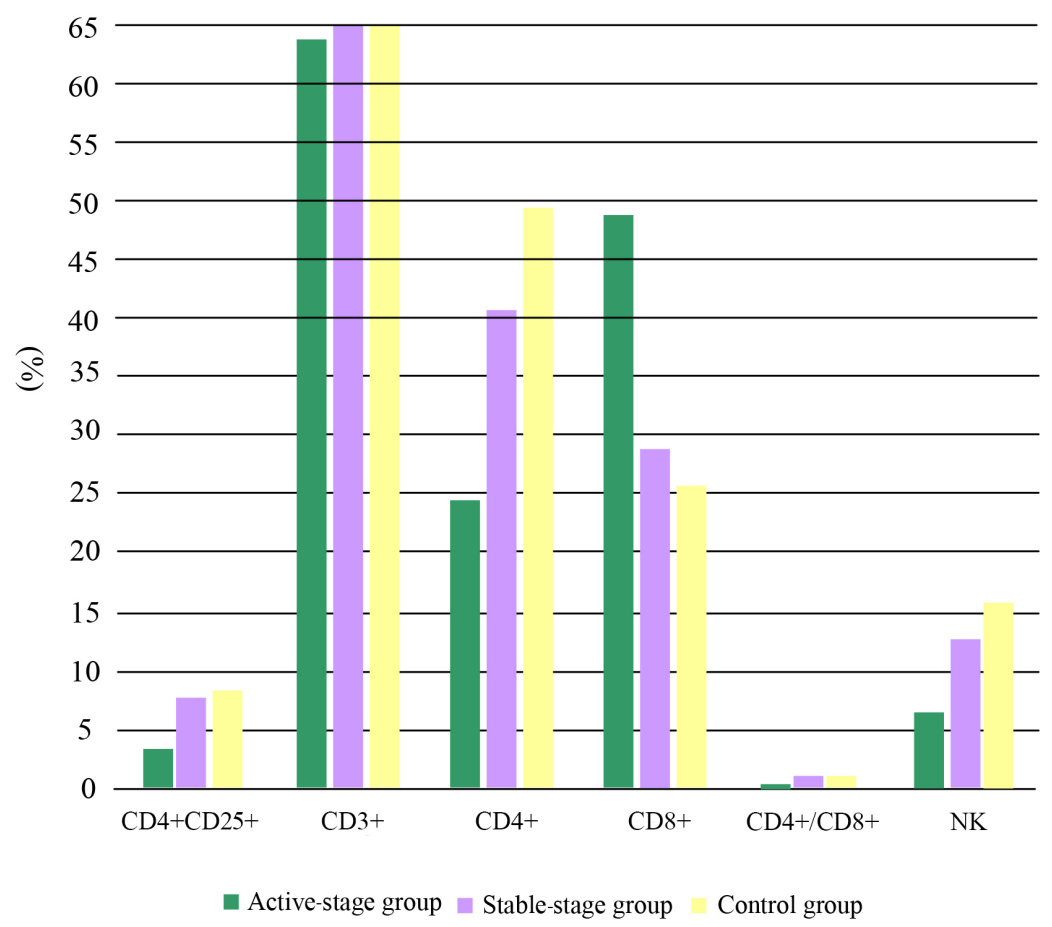

Figure 1. Comparison of T cell subpopulation between the three groups.

\section{Comparison of Ig and complement expression between the three groups}

The active-stage group showed a significant increase in $\operatorname{IgA}, \operatorname{IgG}$, and $\operatorname{IgM}$ expression and a significant decrease in the $\mathrm{C}_{3}$ and $\mathrm{C}_{4}$ levels compared to the stable-stage and control groups $(\mathrm{P}<0.05)$. However, these indices did not differ significantly between the control and stable-stage groups $(\mathrm{P}>0.05$; Table 1$)$.

Table 1. Comparison of peripheral blood immunoglobulin and complement expression between control, stable-stage, and active-stage groups (means $\pm \mathrm{SD}$ ).

\begin{tabular}{l|c|c|c|c|c}
\hline Group & $\operatorname{IgA}(\mathrm{g} / \mathrm{L})$ & $\operatorname{IgG}(\mathrm{g} / \mathrm{L})$ & $\operatorname{IgM}(\mathrm{g} / \mathrm{L})$ & $\mathrm{C}_{3}(\mathrm{~g} / \mathrm{L})$ & $\mathrm{C}_{4}(\mathrm{~g} / \mathrm{L})$ \\
\hline Control group & $3.2 \pm 0.4$ & $11.2 \pm 1.8$ & $1.21 \pm 0.17$ & $1.42 \pm 0.22$ & $0.46 \pm 0.06$ \\
\hline Stable-stage group & $3.9 \pm 0.6$ & $13.1 \pm 2.2$ & $1.41 \pm 0.19$ & $1.32 \pm 0.22$ & $0.40 \pm 0.07$ \\
\hline Active-stage group & $6.1 \pm 1.1$ & $21.4 \pm 3.6$ & $2.01 \pm 0.33$ & $0.89 \pm 0.14$ & $0.15 \pm 0.01$ \\
\hline
\end{tabular}

\section{Comparison of inflammatory factor expression between the three groups}

We also observed a significant increase in the expression of TNF- $\alpha$, IL-10, IL-17, and IFN- $\gamma$ in the active-stage group compared to the control and stable-stage groups $(\mathrm{P}<0.05)$; however, these indices did not differ significantly between the control and stable-stage groups (P > 0.05; Table 2). 
Table 2. Comparison of inflammatory factor expression between groups (means $\pm \mathrm{SD}$ ).

\begin{tabular}{l|c|c|c|c}
\hline Group & TNF- $\alpha(\mathrm{pg} / \mathrm{mL})$ & $\mathrm{IL}-10(\mathrm{pg} / \mathrm{mL})$ & $\mathrm{IL}-17(\mathrm{pg} / \mathrm{mL})$ & $\mathrm{IFN}-\gamma(\mathrm{pg} / \mathrm{mL})$ \\
\hline Active-stage group $(\mathrm{N}=40)$ & $23 \pm 34^{* *}$ & $6 \pm 7^{* *}$ & $48 \pm 33^{* *}$ & $3.2 \pm 3.2^{* *}$ \\
\hline Stable-stage group $(\mathrm{N}=40)$ & $81 \pm 11$ & $30 \pm 6$ & $104 \pm 14$ & $14.1 \pm 2.5$ \\
\hline Control group $(\mathrm{N}=50)$ & $60 \pm 11$ & $21 \pm 2$ & $83 \pm 14$ & $12.8 \pm 2.2$
\end{tabular}

$* \mathrm{P}<0.05$ compared to the control group. ${ }^{*} \mathrm{P}<0.05$ compared to the stable-stage group. TNF- $\alpha$, tumor necrosis factor- $\alpha$; IL-10, interleukin-10; IL-17, interleukin-17; IFN- $\gamma$, interferon- $\gamma$.

\section{Comparison of adhesion molecule expression between the three groups}

We also observed a significant increase in the levels of ICAM-1, VCAM-1, and E-selectin in the active-stage group, compared to the control and stable-stage groups $(\mathrm{P}<$ $0.05)$. However, these indices did not differ significantly between the control and stable-stage groups ( $\mathrm{P}>0.05$; Table 3$)$.

Table 3. Comparison of adhesion molecule expression between the control, active-stage, and stable-stage groups (means $\pm \mathrm{SD}$ ).

\begin{tabular}{l|c|c|c}
\hline Group & ICAM-1 $(\mathrm{pg} / \mathrm{mL})$ & VCAM-1 $(\mathrm{pg} / \mathrm{mL})$ & E-selectin $(\mathrm{pg} / \mathrm{mL})$ \\
\hline Active-stage group $(\mathrm{N}=40)$ & $0.79 \pm 0.13^{* \#}$ & $67.72 \pm 10.12^{* \#}$ & $0.41 \pm 0.08^{* \#}$ \\
\hline Stable-stage group $(\mathrm{N}=40)$ & $0.48 \pm 0.07$ & $35.23 \pm 5.41$ & $0.07 \pm 0.01$ \\
\hline Control group $(\mathrm{N}=50)$ & $0.43 \pm 0.08$ & $22.39 \pm 3.46$ & $0.04 \pm 0.01$ \\
\hline
\end{tabular}

${ }^{*} \mathrm{P}<0.05$ compared to the control group. ${ }^{*} \mathrm{P}<0.05$ compared to the stable-stage group. ICAM-1, intracellular adhesion molecule; VCAM-1, vascular cell adhesion molecule.

\section{DISCUSSION}

The imbalance in CD4+CD25+-regulatory $\mathrm{T}$ cell expression results in T lymphocyte dysfunction and generation of a large amount of $\mathrm{B}$ cell autoantibodies in infection-mediated autoimmune disease. NK cell imbalance has been shown to induce increased autoantibody production and humoral immunity hyperfunction; this, in turn, leads to the formation of antigen-antibody complexes that activate the complement system, inducing a decrease in $\mathrm{C}_{3}$ and $\mathrm{C}_{4}$ expression. Finally, this leads to multiple-organ failure and tissue injury (Hongo et al., 2012; Schliesser et al., 2012). The results of this study indicated a significant decrease in CD4+ cells, CD4+/CD8+ cells, NK cells, $\mathrm{C}_{3}$, and $\mathrm{C}_{4}$, and a significant increase in CD8+ cells, IgA, $\mathrm{IgG}$, and IgM in the active-stage group $(\mathrm{P}<0.05)$; however, there were no obvious changes in the expression of $\mathrm{CD} 3+$ cells $(\mathrm{P}>0.05)$. On the other hand, the difference between the stablestage and control groups was not significant $(\mathrm{P}>0.05)$. This indicated an imbalance in the immune functions in the cells and body fluids during the active stage of autoimmune disease. Downregulated CD4+/CD8+ cell expression is an important indicator of the severity and prognosis of disease (Gu et al., 2008). During the stable stage, there is a marked improvement in all indices, suggesting a relief in immune dysfunction.

CD4+CD25+-regulatory $\mathrm{T}$ cell, a newly identified protective immune-regulatory molecule, inhibits the activation and proliferation of CD4+ T cells, CD8+ T cells, and NK cells, as well as the generation of B cell antibodies (Sakaguchi et al., 2010). Abnormal expression of $\mathrm{CD} 4+\mathrm{CD} 25+$-regulatory $\mathrm{T}$ cells can induce autoimmune diseases such as MS, idiopathic thrombocytopenic purpura, autoimmune hepatitis, and primary biliary cirrhosis; in

Genetics and Molecular Research 15 (3): gmr.15038745 
fact, previous studies have concluded that reduced regulatory $\mathrm{T}$ cell expression and functional defects induce the occurrence and development of autoimmune disease (McKarns and Schwartz, 2005; Wang et al., 2010). The results of this study suggest a significant decrease in the $\mathrm{CD} 4+\mathrm{CD} 25+$-regulatory $\mathrm{T}$ cell expression in the active stage group $(\mathrm{P}<0.05)$; however, the difference in $\mathrm{CD} 4+\mathrm{CD} 25+$-regulatory $\mathrm{T}$ cell expression between the stable-stage and control groups did not differ significantly $(\mathrm{P}>0.05)$, which was consistent with the results reported by Habibagahi et al. (2011). This indicated the involvement of CD4+CD25+-regulatory T cells in the onset of autoimmune disease, and its close correlation with disease activity.

Previous studies have also suggested a correlation between the expression of adhesion molecules and the occurrence of rheumatoid arthritis, SLE, and psoriasis; moreover, the pathogenic mechanism was thought to be associated with the activation of leukocytes and the invasion of inflammatory cells (Lim et al., 2005; Lowes et al., 2008). Our results showed a significant increase in the expression of TNF- $\alpha$, IL-10, IL-17, IFN- $\gamma$, ICAM-1, VCAM-1, and E-selectin in the cells of the active-stage group $(\mathrm{P}<0.05)$; however, this difference was not significant between the cells of the stable-stage and control groups $(\mathrm{P}>0.05)$, suggesting a correlation between the imbalance between cell and regulatory factors and the occurrence of autoimmune disease.

In conclusion, immune dysfunction and inflammatory reactions play important roles in the different stages of the occurrence and development of autoimmune disease; specifically, abnormalities in immune indices, such as inflammatory factor, $\mathrm{T}$ lymphocyte subpopulation, and Ig expression, during the active stage of the disease can be indicative of poor prognosis. Monitoring the changes in immune index and inflammatory reaction can play a major role in understanding the immunological state of the disease, thereby guiding the course of clinical treatment.

\section{Study limitations}

We observed a significant decrease in the CD4+CD25+-regulatory T cells in the activestage group compared to the control group. However, van Amelsfort et al. (2004) reported a significant increase in the expression of CD4+CD25+-regulatory $\mathrm{T}$ cells in the peripheral blood of patients with rheumatoid arthritis, compared to the complete lack of expression observed in the normal people included in the active-stage group. This inconsistency in the results might be correlated with the differences in analyzed disease categories or the degree of active-stage of the disease in the different stages. The regulatory $\mathrm{T}$ cell phenotype and the functional status of patients with autoimmune disease are unstable and complex, and remain to be elucidated.

\section{Conflicts of interest}

The authors declare no conflict of interest.

\section{ACKNOWLEDGMENTS}

The authors sincerely thank the service from Binzhou People's Hospital.

\section{REFERENCES}

Chong BF, Tseng LC, Kim A, Miller RT, et al. (2014). Differential expression of BAFF and its receptors in discoid lupus erythematosus patients. J. Dermatol. Sci. 73: 216-224. http://dx.doi.org/10.1016/j.jdermsci.2013.11.007

Genetics and Molecular Research 15 (3): gmr.15038745 
Fairfax K, Mackay IR and Mackay F (2012). BAFF/BLyS inhibitors: A new prospect for treatment of systemic lupus erythematosus. IUBMB Life 64: 595-602. http://dx.doi.org/10.1002/iub.1046

Gu YS, Kong J, Cheema GS, Keen CL, et al. (2008). The immunobiology of systemic sclerosis. Semin. Arthritis Rheum. 38: 132-160. http://dx.doi.org/10.1016/j.semarthrit.2007.10.010

Habibagahi M, Habibagahi Z, Jaberipour M and Aghdashi A (2011). Quantification of regulatory T cells in peripheral blood of patients with systemic lupus erythematosus. Rheumatol. Int. 31: 1219-1225. http://dx.doi.org/10.1007/ $\underline{\text { s00296-010-1427-0 }}$

Haugen M, Frederiksen JL and Degn M (2014). B cell follicle-like structures in multiple sclerosis-with focus on the role of B cell activating factor. J. Neuroimmunol. 273: 1-7. http://dx.doi.org/10.1016/j.jneuroim.2014.05.010

Hongo D, Tang X, Dutt S, Nador RG, et al. (2012). Interactions between NKT cells and Tregs are required for tolerance to combined bone marrow and organ transplants. Blood 119: 1581-1589. http://dx.doi.org/10.1182/ blood-2011-08-371948

Lim HW, Hillsamer P, Banham AH and Kim CH (2005). Cutting edge: direct suppression of B cells by CD4 $4^{+} \mathrm{CD}_{25} 5^{+}$ regulatory T cells. J. Immunol. 175: 4180-4183. http://dx.doi.org/10.4049/jimmunol.175.7.4180

Lisak RP and Ragheb S (2012). The role of B cell-activating factor in autoimmune myasthenia gravis. Ann. N. Y. Acad. Sci. 1274: 60-67. http://dx.doi.org/10.1111/j.1749-6632.2012.06842.x

Liu $\mathrm{Z}$ and Davidson A (2011). BAFF inhibition: a new class of drugs for the treatment of autoimmunity. Exp. Cell Res. 317: 1270-1277. http://dx.doi.org/10.1016/j.yexcr.2011.02.005

Lowes MA, Kikuchi T, Fuentes-Duculan J, Cardinale I, et al. (2008). Psoriasis vulgaris lesions contain discrete populations of Th1 and Th17 T cells. J. Invest. Dermatol. 128: 1207-1211. http://dx.doi.org/10.1038/sj.jid.5701213

McKarns SC and Schwartz RH (2005). Distinct effects of TGF-beta 1 on CD4+ and CD8+ T cell survival, division, and IL-2 production: a role for T cell intrinsic Smad3. J. Immunol. 174: 2071-2083. http://dx.doi.org/10.4049/ ¡immunol.174.4.2071

Sakaguchi S, Miyara M, Costantino CM and Hafler DA (2010). FOXP3+ regulatory T cells in the human immune system. Nat. Rev. Immunol. 10: 490-500. http://dx.doi.org/10.1038/nri2785

Schliesser U, Streitz M and Sawitzki B (2012). Tregs: application for solid-organ transplantation. Curr. Opin. Organ Transplant. 17: 34-41. http://dx.doi.org/10.1097/MOT.0b013e32834ee69f

Stohl W, Hiepe F, Latinis KM, Thomas M, et al.; BLISS-52 Study Group; BLISS-76 Study Group (2012). Belimumab reduces autoantibodies, normalizes low complement levels, and reduces select B cell populations in patients with systemic lupus erythematosus. Arthritis Rheum. 64: 2328-2337. http://dx.doi.org/10.1002/art.34400

Szydłowski M, Jabłońska E and Juszczyński P (2014). FOXO1 transcription factor: a critical effector of the PI3K-AKT axis in B-cell development. Int. Rev. Immunol. 33: 146-157. http://dx.doi.org/10.3109/08830185.2014.885022

van Amelsfort JM, Jacobs KM, Bijlsma JW, Lafeber FP, et al. (2004). CD4(+)CD25(+) regulatory T cells in rheumatoid arthritis: differences in the presence, phenotype, and function between peripheral blood and synovial fluid. Arthritis Rheum. 50: 2775-2785. http://dx.doi.org/10.1002/art.20499

Vincent FB, Saulep-Easton D, Figgett WA, Fairfax KA, et al. (2013). The BAFF/APRIL system: emerging functions beyond B cell biology and autoimmunity. Cytokine Growth Factor Rev. 24: 203-215. http://dx.doi.org/10.1016/j. cytogfr.2013.04.003

Vincent FB, Morand EF, Schneider P and Mackay F (2014). The BAFF/APRIL system in SLE pathogenesis. Nat. Rev. Rheumatol. 10: 365-373. http://dx.doi.org/10.1038/nrrheum.2014.33

Volpe E, Servant N, Zollinger R, Bogiatzi SI, et al. (2008). A critical function for transforming growth factor-beta, interleukin 23 and proinflammatory cytokines in driving and modulating human $\mathrm{T}(\mathrm{H})-17$ responses. Nat. Immunol. 9: 650-657. http://dx.doi.org/10.1038/ni.1613

Wang D, Zhang H, Liang J, Gu Z, et al. (2010). CD4+ CD25+ but not CD4+ Foxp3+ T cells as a regulatory subset in primary biliary cirrhosis. Cell. Mol. Immunol. 7: 485-490. http://dx.doi.org/10.1038/cmi.2010.40

Zouali M and Uy EA (2013). Belimumab therapy in systemic lupus erythematosus. BioDrugs 27: 225-235. http://dx.doi. org/10.1007/s40259-013-0031-8

Genetics and Molecular Research 15 (3): gmr.15038745 